DOI: http://dx.doi.org/10.17651/ONOMAST.64.24

Onomastica LXIV, 2020

EWA WOLNICZ-PAWŁOWSKA

PL ISSN 0078-4648

ewolnicz@poczta.onet.pl

https://orcid.org/0000-0002-5957-7854

Komisja Nazw Miejscowości i Obiektów Fizjograficznych

Warszawa, Polska

\title{
W SŁUŻBIE NAUKI I KRAJU. WSPOMNIENIE O PANI PROFESOR ALEKSANDRZE CIEŚLIKOWEJ
}

\author{
Słowa tematyczne: Aleksandra Cieślikowa, osiągnięcia naukowe, działalność ekspercka
}

Tytuł wspomnienia może wydawać się nazbyt patetyczny, jednak trudno znaleźć lepsze określenie na postawę życiową, którą reprezentowała prof. Aleksandra Cieślikowa, mianowicie postawę powinnościową naukowca wobec społeczeństwa. Tradycyjnie wiąże się takie nastawienie do życia z polską inteligencją. Ta warstwa społeczna — jak i samo słowo ,inteligencja” w znaczeniu grupy społecznej — została ochoczo pogrzebana przez socjologów (a za nimi publicystów), a przecież casus Pani Profesor nie jest bynajmniej wyjątkiem. Służba dla społeczeństwa i narodu ma u nas długą tradycję i nie zanosi się (na szczęście), aby miała zaniknąć. Zmienił się za to sposób mówienia o potrzebach społecznych i ich zaspokajaniu. Wielu z nas jest z pewnością bardziej powściągliwych, a nawet niechętnych werbalizowaniu swoich społecznikowskich intencji.

Jakiś czas temu, pisząc artykuł o początkach Towarzystwa Naukowego Warszawskiego ${ }^{1}$, natrafiłam na taki fragment w opracowaniu Marcelego Handelsmana:

Na nich wszystkich [pisze autor o inicjatorach powstania Towarzystwa], jak i na całym tym pierwszym popowstaniowym pokoleniu, pozytywizm wycisnął swoje piętno wyraźne [...]. Cechowały ich głębokie i religijne przywiązanie do Nauki, wiara w jej wszechpotęgę i najwyższe posłannictwo w narodzie i ludzkości, poszukiwanie praw niezmiennych rozwoju w tej dziedzinie, która była dziedziną ich własnych wysiłków badawczych, a zarazem uczuciowe przywiązanie własnej działalności naukowej z obowiązkiem pracy dla innych, dla społeczeństwa, nakaz zrzeszania się i zbiorowego, bezinteresownego wtajemniczania niewtajemniczonych w odsłanianie prawdy (Handelsman, 1932, s. 70).

Ten cytat, jak mi się wydaje, świetnie pasuje także do naszych mistrzów i nauczycieli, którzy kształtowali postawy życiowe obecnego starszego i najstarszego pokolenia, w tym również poglądy na miejsce i rolę nauki w życiu społecznym. I chociaż nasi wychowawcy nie czuli już takiego „religijnego przywiązania do Nauki” i „wiary w jej wszechpotęgę”, jak pokolenie Szkoły Głównej, to jednak podzielali oni z tym pokoleniem zasadnicze, ogólne wartości. Odwołam się do sformułowań Stanisława Gajdy, który tak pisał, rozważając cechy stylu naukowego:

${ }^{1}$ Wiele osób powołujących do życia Towarzystwo Naukowe Warszawskie było członkami krakowskiej Akademii Umiejętności, por.: „Po zatwierdzeniu statutu przez władze carskie w dniu 1 marca 1907 r. w gronie pierwszych piętnastu członków założycieli TNW aż dziewięciu było członkami Akademii Umiejętności. Byli to: Ignacy Chrzanowski, Samuel Dickstein, Władysław Gosiewski, Henryk Hoyer, Aleksander Jabłonowski, Jan Kowalczyk, Adam Antoni Kryński, Władysław Smoleński i Teodor Wierzbowski" (Zasztowt, 2018, s. 12). 
Aby osiągnąc wiedzę idealną lub bliską ideału, trzeba strzec pewnych wartości w praktyce poznawczo-komunikacyjnej. W działalności naukowej, zgodnej z kanonami paradygmatu naukowego obowiązującego współcześnie w naszej kulturze, podstawowe znaczenie mają wartości poznawcze łączone przede wszystkim z prawdą — nauka dąży do wiedzy prawdziwej i pewnej, tj. absolutnie odpowiadającej pewnemu stanowi rzeczy (według klasycznej definicji prawdy). Idealna wiedza powinna być uporządkowana logicznie oraz odznaczać się wysoką zawartością informacyjną i głębią, co pociąga za sobą jej ścisłość, racjonalność i abstrakcyjność (Gajda, 2001a, s. 184).

Profesor A. Cieślikowa reprezentowała kolejne pokolenie polskich badaczy fundujących swoją aktywność na wartościach opisywanych wyżej. W jej działalności naukowej wyraźnie widać dążenie do odkrywania prawdy, poznania i dogłębnej analizy zjawisk językowych, troskę o poziom prac naukowych (własnych i ocenianych), popularyzację wiedzy rzetelnej i przydatnej szerokiemu gronu odbiorców. Zarazem należałoby wymienić jeszcze inne właściwości Jej zachowania, zharmonizowane z wymienionymi wyżej, a mianowicie owo opisywane przez Handelsmana powiązanie własnej działalności naukowej z obowiązkiem pracy dla innych oraz umiejętność pracy zespołowej, czy to w podejmowaniu i realizacji zadań poruczonych przez zwierzchników, czy w organizacji i wykonaniu projektów kierowanych przez samą Panią Profesor. A do tego skromność i naturalność, tak ujmujące w jej zachowaniu. W swoich tekstach zachowała tradycyjną dla stylu naukowego ścisłość, racjonalność i abstrakcyjność, co warto podkreślić wobec nowych tendencji na przełomie XX i XXI w., na które wskazywał S. Gajda: „Następuje rozluźnienie norm stylowych języka naukowego, pojawiają się w nim wpływy innostylowe (publicystyczne, artystyczne i potoczne). Kontekst odkrycia i zwłaszcza retoryczny zaczynają brać górę nad kontekstem uzasadnienia" (Gajda, 2001b, s. 185).

\section{W SŁUŻBIE NAUKI}

Profesor A. Cieślikową poznałam najpierw na konferencjach onomastycznych. Ja dopiero uczyłam się warsztatu onomasty, ona była już wdrożona w problematykę tej dziedziny i miała własny, liczący się dorobek naukowy. Zaczynała w zespole opracowującym „Słownik staropolskich nazw osobowych”, a to zadanie cieszyło się ogromnym szacunkiem wszystkich językoznawców ${ }^{2}$. Na bazie materiału „Słownika” zaczęła publikować pierwsze autorskie studia. Dla całego onomastycznego świata, nie tylko w Polsce, ważnym wydarzeniem były jej książkowe publikacje o procesie onimizacji (Cieślikowa, 1990) oraz o derywacji paradygmatycznej w staropolskiej antroponimii (Cieślikowa, 1991). Wyszła w nich poza schematy dotychczasowych opracowań onomastycznych, wywodzących się jeszcze z dziewiętnastowiecznego językoznawstwa diachronicznego, wprowadzając elementy analizy zaczerpnięte z nowych nurtów badawczych, a także nowe propozycje metodologiczne i terminologiczne. Zainteresowania teoretyczne (dodajmy — nieczęste w polskiej onomastyce) stale towarzyszyły twórczości naukowej Pani Profesor. Szczególnie zainteresowała mnie druga z wymienionych wyżej książek, ponieważ poszerzała i porządkowała wiedzę o słabo wówczas zbadanej derywacji paradygmatycznej w antroponimii ${ }^{3}$. Napisałam wtedy szczegółową recenzję tej pracy (Wolnicz-Pawłowska, 1993) i na trwałe włączyłam do swego warsztatu badawczego propozycje Koleżanki.

${ }^{2}$ Warto przytoczyć spojrzenie „od wewnątrz” zespołu: „Praca w zespole przygotowującym Stownik staropolskich nazw osobowych była bardzo wyczerpująca, kilkadziesiąt lat pracy, niekiedy po wiele godzin dziennie. Dzięki wysiłkowi zespołu powstało dzieło wybitne, ale pracownikom mało dające. Każdy z nas zredagował z pewnością duży tom, ale była to praca anonimowa. Dawała, co prawda, drobiazgową wiedzę o nazwach osobowych, ale równocześnie ograniczała zakres badawczy. Uprawianie własnej działalności naukowej wymagało wielu wyrzeczeń” (Rymut, 2006, s. 7).

${ }^{3} \mathrm{Na}$ warszawskich studiach polonistycznych, które kończyłam, do słowotwórstwa przywiązywano dużą wagę ze względu na zainteresowania naukowe naszych wykładowców, jednak akurat ten rodzaj tworzenia nowych jednostek leksykalnych miał wtedy opisy ograniczone w zasadzie do tzw. derywacji wstecznej. 
Z czasem nasze naukowe kontakty nabrały nowego wymiaru przy okazji współpracy nad dużym projektem badawczym, jakim była pierwsza polska encyklopedia onomastyczna (Rzetelska-Feleszko (red.), 1998). Przy innych projektach stałam się recenzentem, wdzięcznym i uważnym czytelnikiem zarówno prac zbiorowych, kierowanych przez prof. Cieślikową (np. „Słownik etymologiczno-motywacyjny staropolskich nazw osobowych”, „Antroponimia Polski XVI-XVIII w.”, „,Słowiańska onomastyka. Encyklopedia”4), jak też artykułów nadsyłanych do „Onomastików”, w których pełniła funkcję najpierw sekretarza redakcji (od 1994 r.), potem redaktora, wreszcie redaktora naczelnego (od 2006 r.). Ważny poznawczo był dla mnie jej artykuł o elementach wschodniosłowiańskich w staropolskich nazwach osobowych pochodzenia ruskiego (Cieślikowa, 2000). Udowodniła, że takie nazwy występowały nie tylko we wschodnich regionach kraju, ale także — i to wcale licznie na zachodzie, świadcząc o mobilności ówczesnego społeczeństwa. Szczególne miejsce w moich wspomnieniach zajmuje wspólnie napisana przedmowa do wykazu standaryzowanych hydronimów (Cieślikowa i Wolnicz-Pawłowska, 2006) oraz artykuł o nazwisku Wolnicz (Cieślikowa, 2013). Do księgi pamiątkowej samej Pani Profesor (Rymut (red.), 2006) nie zdążyłam z tekstem, ale napisałam specjalnie dla niej artykuł, opublikowany w „Onomastikach”: „Baba w polskiej toponimii” (Wolnicz-Pawłowska, 2005) $)^{5}$.

Nasze zainteresowania badawcze często się spotykały; tak było np. w kwestii adaptacji i tłumaczenia nazw obcych czy polityki nazewniczej. Niejednokrotnie odkrywałam, podejmując jakiś temat, że już wcześniej Ksenia poruszała podobne zagadnienia w swoich licznych artykułach, rozsianych po różnych pismach i zbiorach pokonferencyjnych polskich i zagranicznych, jako że uczestniczyła w wielu spotkaniach międzynarodowych. Po latach powiedziałam jej o tym, sugerując, że dobrze byłoby zebrać w jednej publikacji te perełki onomastyczne i normatywistyczne. Na pewno było jej miło to słyszeć, ale nie czuła się już na siłach, aby podejmować prace redakcyjne i wracać do dawnych publikacji.

\section{W SŁUŻBIE KRAJU}

Zgromadzona wiedza onomastyczna przydała się prof. A. Cieślikowej w ciałach normatywnych, takich jak Komisja Onomastyczno-Ortograficzna w Radzie Języka Polskiego czy Komisja Nazw Miejscowości i Obiektów Fizjograficznych w Ministerstwie Spraw Wewnętrznych i Administracji. Jako członek Rady Języka Polskiego przygotowała poszerzoną listę imion do stosowania w urzędach stanu cywilnego (Rymut, 2006). Wielokrotnie opiniowała także prośby o rozstrzygnięcia poprawnościowe odnoszące się do nazw miejscowych, polskich i zagranicznych. W tej działalności wykorzystywała swoje doświadczenia z Komisji Nazw Miejscowości i Obiektów Fizjograficznych. Działalność w tej ostatniej instytucji znam lepiej i dokładniej niż w Radzie Języka Polskiego. Zaczęła pracować w KNMiOF jako ekspert od 1989 r. jeszcze za czasów przewodnictwa prof. Kazimierza Rymuta, a po jego rezygnacji to ona objęła przewodniczenie (od listopada 2004 r.). Chociaż zasadniczo jej dorobek naukowy dotyczył antroponimii, to w nowych, toponimicznych wyzwaniach świetnie się odnalazła. Ja mniej więcej w tym samym czasie zaczęłam uczestniczyć w pracach siostrzanej Komisji Standaryzacji Nazw Geograficznych poza Granicami Kraju przy Głównym Geodecie Kraju, zatem obie równocześnie weszłyśmy w problematykę poprawnościową nazw geograficznych. Praca w komisjach nazewniczych ma swoją specyfikę i wymaga nie tylko wiedzy teoretycznej (onomastycznej, historycznej, terminoznawczej itp.), ale także znajomości reguł postępowania administracyjnego i potrzeb społecznych (por. Wolnicz-Pawłowska, 2011). Naukowcy — członkowie komisji, uczestniczący w procesie standaryzacji, służą krajowi swoją wiedzą i kompetencjami, jak potrafią najlepiej. W czasie kadencji prof. A. Cieślikowej w Komisji członkami byli też: prof. Barbara

${ }^{4}$ Rec. tej publikacji por. Wolnicz-Pawłowska, 2004.

${ }_{5}^{5}$ Pięćdziesiąty numer czasopisma zadedykowano prof. Kazimierzowi Rymutowi, ale akurat swój artykuł napisałam dla Kseni. 
Czopek-Kopciuch, prof. Robert Mrózek i ja. Podobny skład istniał w czasie następnej kadencji, już pod przewodnictwem prof. Barbary Czopek-Kopciuch. Zespół ten miał wyraźne zainteresowania teoretyczne i metodologiczne, wszyscy też uczestniczyliśmy w różnych gremiach onomastycznych i uczelnianych, toteż szybko ustalił się zwyczaj poobradowych obiadów, na które tradycyjnie szliśmy po posiedzeniu, aby omówić aktualne problemy i przedyskutować tematy, nad którymi pracowaliśmy. Jednym z takich tematów były np. kompetencje Komisji. Trzeba podkreślić, że Komisja jest ciałem doradczym, a nie decyzyjnym, więc ostateczny efekt naszej pracy, tj. wykazy urzędowych nazw, nie we wszystkich punktach może się okazać zgodny z naszymi sugestiami. Refleksje o roli językoznawców w komisjach nazewniczych znaleźć można zresztą w wypowiedziach wszystkich w zasadzie przewodniczących, podobnie jak refleksje o zasadach poprawności nazw geograficznych.

Standaryzacyjnej praktyce od początku (tj. od lat 30. XX w.) towarzyszyły uwagi metodologiczne. Zasady, według których postępowano, zmieniały się z czasem, wraz z wymaganiami polityki językowej kraju i ze zmianami w podejściu normatywnym specjalistów od kultury języka. Tak się złożyło, że o polityce językowej i o poprawności językowej w encyklopedii „Polskie nazwy własne” pisałam ja na prośbę prof. Ewy Rzetelskiej-Feleszko, zaś w „Słowiańskiej onomastyce" - prof. A. Cieślikowa. Obie, tworząc hasła w tych encyklopediach, wykorzystywałyśmy swoje doświadczenia z komisji nazewniczych, by potem wspólnie sformułować zasady poprawnościowe we wspomnianej wcześniej przedmowie do wykazu polskich hydronimów standaryzowanych. Wymieniłyśmy następujące kryteria poprawności językowej, którymi także obecnie kierują się obie polskie komisje nazewnicze:

- zgodność brzmienia i pisowni nazwy z zasadami polskiego języka ogólnego,

- etymologia nazwy,

- zapisy historyczne (preferujemy formy utrwalone w historii),

- tradycja używania nazwy w lokalnej wspólnocie,

- częstość występowania na mapach i w innych współczesnych opracowaniach,

- frekwencja poszczególnych form na stronach internetowych.

Poprawność nazw własnych stała się po roku 2000 jednym ze stałych tematów w twórczości onomastycznej prof. A. Cieślikowej, zarówno w autorskich artykułach (np. Cieślikowa, 2004, 2005), jak i w pracach zbiorowych o charakterze popularnym (np. Cieślikowa, 2002). Podbudowa teoretyczna służyła wypracowaniu najlepszych procedur w postępowaniu standaryzacyjnym, za które czuła się odpowiedzialna jako przewodnicząca Komisji Nazw Miejscowości i Obiektów Fizjograficznych.

Chciałabym wspomnieć kilka przypadków mojej współpracy z Panią Profesor na tym polu. Od 2002 r. z inicjatywy urzędu Głównego Geodety Kraju KNMiOF zajęła się standaryzowaniem polskich hydronimów. To ogromne, kilkuletnie zadanie wykonywane było we współpracy z ekspertami zewnętrznymi: hydrologami, którzy opracowali „Atlas hydrologiczny Polski” oraz językoznawcami, autorami monografii hydronimicznych. Pracom przewodniczył prof. Kazimierz Rymut. Wiceprzewodniczącą była wówczas prof. A. Cieślikowa. Na posiedzeniach Komisji występowałam jako gość, a zarazem koordynator współpracy z hydronomastami. Jak wspomniałam wcześniej, w rezultacie powstały dwa tomy wykazów nazw standaryzowanych, zaś przedmowę do tych wykazów napisałyśmy wspólnie. Po ukończeniu prac nad hydronimami Komisja zajęła się nazwami jaskiń. Spotkałyśmy się wtedy obie w Komisji: Pani Profesor jako przewodnicząca, ja jako członek. Miałam wtedy okazję obserwować umiejętność jej pracy zespołowej, kierowanie zadaniami, a także wielki takt w prowadzeniu obrad przy jednoczesnym trzymaniu się naukowych pryncypiów. Komisja pod jej przewodnictwem zmieniła nieco stanowisko w kwestii poprawności językowej, wykazując większą otwartość na lokalny uzus. Problemy poprawnościowe często wiązały się z odmianą nazw miejscowości. Owocem prac w Komisji stała się książeczka pod redakcją Pani Profesor, nieoceniona dla szerokiego kręgu użytkowników, a mianowicie „Mały słownik odmiany nazw własnych” (2002). Z czasem doszła do tego druga podobna praca autorstwa B. Czopek-Kopciuch, U. Bijak i A. Cieślikowej „Mały słownik nazw polskich miast, państw Europy, ich stolic i mieszkańców” (2011).

Okres kierowania przez prof. A. Cieślikową Komisją Nazw Miejscowości i Obiektów Fizjograficznych zbiegł się z nowymi zadaniami Komisji, a mianowicie ustaleniami nazw w językach 
mniejszości narodowych i etnicznych oraz w języku regionalnym ${ }^{6}$. To w czasie kadencji prof. A. Cieślikowej Komisja wypracowała tryb ustalania nazw mniejszościowych. Pierwsze wnioski napłynęły od mniejszości niemieckiej oraz samorządów kaszubskich. Wnioski z gmin o mniejszościowym języku niemieckim zazwyczaj referowała prof. Barbara Czopek-Kopciuch, a nazwy kaszubskie - prof. Aleksandra Cieślikowa. Ustalenie poprawności nazw kaszubskich było zadaniem szczególnie trudnym, gdyż status tego języka regionalnego jest stosunkowo świeży, a wydany słownik toponimów Kaszubszczyzny oceniany był przez językoznawców dość krytycznie. Prof. A. Cieślikowej udało się pozyskać współpracę nieżyjącego już prof. Jerzego Tredera, wybitnego znawcy kaszubszczyzny. Dzięki jego opiniom standaryzacja nazw mniejszościowych z tego obszaru przebiegała bardzo sprawnie.

Drugim zadaniem, z którym przyszło się mierzyć członkom Komisji w tym okresie, był napływ wniosków o zniesienie urzędowych nazw przysiółków, kolonii i części wsi. Co prawda najwięcej tych wniosków rozpatrywaliśmy już w następnej kadencji, pod przewodnictwem prof. Barbary Czopek-Kopciuch, ale wypracowanie reguł postępowania i zasad usuwania bądź pozostawiania nazw takich jednostek osadniczych zaczęło się za kadencji A. Cieślikowej. Powszechny przegląd nazewnictwa geograficznego w gminach był związany z potrzebami utworzonego w tym czasie Państwowego Rejestru Nazw Geograficznych. Gminy miały podać współrzędne geograficzne wskazanych obiektów na swoim terenie. Wiele gmin przy tej okazji chciało ograniczyć zakres nazw urzędowych, zwłaszcza niewielkich jednostek osadniczych, w których mieszkańcy nie byli meldowani. Komisja w swoich decyzjach uwzględniała nie tylko potrzeby lokalnej administracji, ale także interes szerszej społeczności (np. turystów, służb państwowych) oraz dziedzictwo kulturowe całego narodu.

Kończąc to wspomnienie o prof. Aleksandrze Cieślikowej, chciałabym jeszcze raz podkreślić jej ogromne ciepło i ludzką życzliwość. Ogarniała sercem całą społeczność polskich onomastów, pamiętała o jubileuszach kolegów (por. np. Cieślikowa, 2014) i dbała o pamięć tych, którzy odeszli. Choćby z tych względów zasłużyła sobie na wdzięczność całego środowiska. I jeszcze akcent onomastyczny o bardzo osobistym wymiarze: do Kseni zwracałam się per Kseniutku, a ona do mnie: Ewusiu.

\section{LITERATURA}

Cieślikowa, A. (1990). Staropolskie odapelatywne nazwy osobowe. Proces onimizacji [Old Polish personal names from appellatives. The process of onymization]. Wrocław-Warszawa-Kraków: Zakład Narodowy im. Ossolińskich.

Cieślikowa, A. (1991). Derywacja paradygmatyczna w staropolskiej antroponimii [Paradigmatic derivation in Old Polish anthroponymy]. Kraków: Instytut Języka Polskiego PAN.

Cieślikowa, A. (2000). Formy wschodniosłowiańskie w średniowiecznych przezwiskach [Eastern Slavic forms in medieval nicknames]. W: E. Wolnicz-Pawłowska i W. Szulowska (red.), Kontakty językowe polszczyzny na pograniczu wschodnim. Prace ofiarowane profesorowi Januszowi Riegerowi [Language contacts of the Polish language on the eastern frontier. Works offered to Professor Janusz Rieger] (s. 31-35). Warszawa: Wydawnictwo Naukowe Semper.

Cieślik ow a, A. (red.). (2002). Mały stownik odmiany nazw własnych [A small dictionary of proper names inflection]. Kraków: Instytut Języka Polskiego PAN, TMJP.

Cieślikowa, A. (2002). Polityka i pragmatyka w zakresie nazw własnych [Politics and pragmatics in the field of proper names]. W: E. Rzetelska-Feleszko, A. Cieślikowa i J. Duma (red.), Stowiańska onomastyka. Encyklopedia [Slavic onomastics. Encyclopedia] (t. 1, s. 262-264). Warszawa-Kraków: Towarzystwo Naukowe Warszawskie.

Cieślikowa, A. (2004). Normatywny aspekt nazw własnych [Normative aspect of proper names]. W: R. Mrózek (red.), Nazwy własne w języku, kulturze i komunikacji społecznej [Proper names in language, culture and social communication] (s. 229-239). Katowice: Wydawnictwo Uniwersytetu Śląskiego.

\footnotetext{
${ }^{6}$ Pierwszą nazwę — w języku niemieckim — Komisja ustaliła w 2006 r.
} 
Cieślikowa, A. (2005). Nazwy własne w historii i we współczesności języka polskiego [Proper names in the history and in the contemporary Polish language]. W: S. Borawski, Rozprawy o historii języka polskiego [Dissertations on the history of the Polish language] (s. 101-148). Zielona Góra: Oficyna Wydawnicza Uniwersytetu Zielonogórskiego.

Cieślikowa, A. (2013). O nazwisku Wolnicz i o kilku innych, a także o nazwach miejscowych z sufiksem -icz [About the surname Wolnicz and a few others, as well as place names with the suffix -icz]. W: E. Dzięgiel, T. Korpysz (red.), Niejedno ma imię... Prace onomastyczne i dialektologiczne dedykowane Profesor Ewie Wolnicz-Pawłowskiej [Onomastic and dialectological works dedicated to Professor Ewa Wolnicz-Pawłowska] (s. 61-71). Warszawa: Wydawnictwo Uniwersytetu Kardynała Stefana Wyszyńskiego.

Cieślikowa, A. (2014). Osiągnięcia onomastyczne jubilatów [Onomastic achievements of the jubilarians]. W: A. Gałkowski, R. Gliwa (red.), Mikrotoponimia i makrotoponimia. Problematyka wstęp$n a$ [Microtoponymy and macrotoponymy. Preliminary problems] (s. 321-329). Łódź: Wydawnictwo Uniwersytetu Łódzkiego.

Cieślikowa, A. i Wolnicz-Pawłowska, E. (2006). Przedmowa [Preface]. W: E. Wolnicz-Pawłowska i in., Nazewnictwo geograficzne Polski. T. I. Hydronimy. Cz. 1. Wody plynące, źródła, wodospady [Geographical names of Poland. Vol. I. Hydronyms. Part 1. Flowing waters, sources, waterfalls] (s. VII-XIV). Warszawa: GUGiK.

Czopek-Kopciuch B., Bijak U. i Cieślikowa, A. (2011). Mały stownik nazw polskich miast, państw Europy, ich stolic i mieszkańców [A small dictionary of the names of Polish cities, European countries, their capitals and inhabitants]. Warszawa-Kraków: Oficyna Wydawnicza RYTM.

Gajda, S. (2001a). Styl naukowy [Scientific style]. W: J. Bartmiński (red.), Wspótczesny język polski [Contemporary Polish language] (s. 183-199). Lublin: Wydawnictwo UMCS.

Gajda, S. (2001b). Historia XX-wiecznej polszczyzny literackiej i jej odmian stylowych [History of the 20th-century literary Polish and its style variants]. W: S. Dubisz, S. Gajda (red.), Polszczyzna XX wie$k u$. Ewolucja i perspektywy rozwoju [Polish language of the 20th century. Evolution and development prospects] (s. 175-192). Warszawa: Elipsa.

Handelsman, M. (1932). Towarzystwo Naukowe Warszawskie. 1907-1932 [The Warsaw Scientific Society. 1907-1932]. Warszawa: Towarzystwo Naukowe Warszawskie.

Rymut, K. i in. (red.). (2006). Munuscula linguistica in honorem Alexandrae Cieślikowa oblata. Kraków: Instytut Języka Polskiego PAN.

Rymut, K. (2006). Zamiast wstępu — słów kilka o Profesor Aleksandrze Cieślikowej [Instead of an introduction - a few words about Professor Aleksandra Cieślikowa]. W: K. Rymut i in. (red.), Munuscula Linguistica in honorem Alexandrae Cieślikowa oblata (s. 7-11). Kraków: Instytut Języka Polskiego PAN.

Rzetelska-Feleszko, E. (red.). (1998). Polskie nazwy własne. Encyklopedia [Polish proper names. Encyclopedia]. Warszawa-Kraków: Towarzystwo Naukowe Warszawskie, Instytut Języka Polskiego PAN.

Rzetelska-Feleszko, E., Cieślikowa, A. i Duma, J. (red.). (2002-2003). Stowiańska onomastyka. Encyklopedia (t. 1-2) [Slavic onomastics. Encyclopedia (Vols. 1-2)]. Warszawa-Kraków: Towarzystwo Naukowe Warszawskie.

Wolnicz-Pawłowska, E. (1993). rec. [review of] A. Cieślikowa, Derywacja paradygmatyczna w staropolskiej antroponimii, Kraków 1991. Onomastica, 38, 289-295.

Wolnicz-Pawłowska, E. (1998). Problemy poprawności nazw. Polityka nazewnicza [The problems of correctness of proper names. Naming policy]. W: E. Rzetelska-Feleszko (red.), Polskie nazwy własne. Encyklopedia [Polish proper names. Encyclopedia] (s. 481-491). Warszawa-Kraków: Towarzystwo Naukowe Warszawskie; Instytut Języka Polskiego PAN.

Wolnicz-Pawłowska, E. (2004). rec. [review of] Słowiańska onomastyka. Encyklopedia, red. E. Rzetelska-Feleszko, A. Cieślikowa przy współudziale J. Dumy, t. I-II, Wyd. Towarzystwo Naukowe Warszawskie, Warszawa-Kraków 2002-2003, 535 + 616 ss. Onomastica, 49, 181-194.

Wolnicz-Pawłowska, E. (2005). Baba w polskiej toponimii [Baba in Polish toponymy]. Onomastica, $50,151-171$. 
Wolnicz-Pawłowska, E. (2011). Naukowiec, ekspert, urzędnik — funkcje i role językoznawcy w procesie standaryzacji nazw geograficznych [Scientist, expert, clerk - functions and roles of a linguist in the process of standardization of geographical names.]. W: M. Biolik, J. Duma (red.), Chrematonimia jako fenomen współczesności [Chrematonymy as a phenomenon of modern times] (s. 519-532). Olsztyn: Wyd. Uniwersytetu Warmińsko-Mazurskiego.

Zasztowt, L. (2019). Towarzystwo Naukowe Warszawskie w pierwszej połowie XX wieku [The Warsaw Scientific Society in the first half of the 20th century]. Rocznik Towarzystwa Naukowego Warszawskiego, 81, 9-22.

\author{
SUMMARY \\ IN THE SERVICE OF SCIENCE AND THE COUNTRY. \\ MEMORIES OF PROFESSOR ALEKSANDRA CIEŚLIKOWA
}

The text is dedicated to the outstanding Polish researcher of proper names — prof. Aleksandra Cieślikowa, author and co-author of many significant monographs and onomasticons, which went beyond the limits of previous onomastic studies. The most important, selected her scientific achievements and expert activities at the Polish Language Council and the Commission on Names of Localities and Physiographic Objects were presented.

Keywords: Aleksandra Cieślikowa, scientific achievements, expert activities 